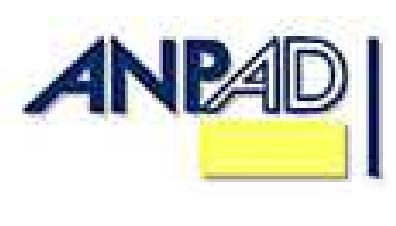

Available online at

http://www.anpad.org.br/bar

BAR, Rio de Janeiro, v. 10, n. 1, art. 2,

pp. 18-39, Jan./Mar. 2013

\title{
The World Financial Crisis and the International Financing of Brazilian Companies
}

\author{
Andre Carvalhal * \\ E-mail address: andrecarvalhal@iag.puc-rio.br \\ Pontifícia Universidade Católica do Rio de Janeiro - IAG/PUC-Rio \\ Rio de Janeiro, RJ, Brazil. \\ Ricardo Pereira Câmara Leal \\ E-mail address: rleal@ufrj.br \\ Universidade Federal do Rio de Janeiro - COPPEAD/UFRJ \\ Rio de Janeiro, RJ, Brazil.
}

* Corresponding author: Andre Carvalhal IAG/PUC-RIO, Rua Marquês de São Vicente, 225, Rio de Janeiro, RJ, 22451-900, Brazil.

Received 19 January 2012; received in revised form 11 June 2012 (this paper has been with the authors for two revisions); accepted 9 July 2012; published online 25 September 2012. 


\begin{abstract}
The world financial crisis initiated in 2008 may have affected the international financing mix of firms in Brazil and their determinants, given its aftereffects. Financial crisis are recurrent events with varying degrees of severity. Many public Brazilian firms use international financing in their capital structure mix and it is relevant to understand their behavior during international crises. Thus, our goal was to investigate the foreign financing mixes of Brazilian listed companies before (2004) and during the 2008 world financial crisis by means of descriptive and probit regression analyses of their components and determinants at the end of these years. Brazilian companies usage of Eurobonds fluctuates with the value of the real $(\mathrm{R} \$)$ and is still small considering the size of Brazil's economy. Short-term financing and bank loans, domestic and foreign, decreased in 2008 and were replaced by domestic and international bonds and American Depository Receipts (ADRs). Firms with foreign shareholders more often resorted to foreign capital markets and their presence became a more important determinant in 2008, while the other determinants did not change. Firms that employ international debt tend to use all other sources of financing more often. International bank loans may be the first step to reduce international financing constraints.
\end{abstract}

Key words: financial crisis; international corporate financing; capital structure; Brazilian listed firms. 


\section{Introduction}

The world financial crisis initiated with the subprime crisis in 2007 in the United States (USA) and spread around the globe. Its outcome is still uncertain. Roubini (2009) believed that the worst was yet to come. The crisis affected capital availability and an ensuing credit crunch reached emerging markets, Brazil included, possibly affecting the mix and the terms of their domestic and international financing. Even though there was an initial perception that the effects of the crisis were minor in Brazil, the recurrence of financial crises motivates a comparative analysis of the behavior of the domestic-international mix and of the determinants of the international financing mix before and during the crisis (Bacha \& Goldfajn, 2009; Dooley \& Hutchison, 2009; O. Barros \& Giambiagi, 2009).

We investigate, thus, the determinants of the international financing components of the capital structure of non-financial Brazilian exchange listed companies before (2004) and during the world financial crisis (2008). We present descriptive financial and capital structure company statistics, according to their sources of international financing, and an analysis of the determinants of international financing before and during the world financial crisis.

The contributions of this article are a qualitative discussion of the potential impact of the financial crisis on credit constrained firms in emerging markets, which leads to testable hypotheses, and a comparative empirical analysis of capital structure indicators and of the determinants of its international components in Brazil before and during the crisis to verify if the evidence supports them. In any case, the evidence presented is preliminary for several reasons: the crisis is still unfolding and we derive our conclusions from a comparison of two years in one specific country. General conclusions could only be drawn from the testing of a general theoretical model of the impacts of the crisis, or of credit constraints, on firms.

Our empirical analysis contemplates the domestic as well as the international portions of Brazilian corporate financing. We are interested in the dynamics of the relative importance of international financing sources and, therefore, cannot ignore the domestic financing side. It is possible that from 2004 to 2008 there were relevant changes in the proportions financed abroad and domestically. Likewise, we cannot ignore the equity portion and, thus, it is also considered. The comparative analysis of the years 2004 and 2008 considers both a domestic-international dimension as well as an equity-debt dimension. However, our emphasis is on the international components of Brazilian corporate financing.

Our preliminary analysis suggests that Brazilian non-financial listed firms suffered the impacts of the crisis. Usage of short-term debt decreased during the crisis, particularly banking loans. Larger firms were able to replace short-term financing with long-term financing, mostly using capital markets (domestic bonds, Eurobonds, and ADR issuance). Firms that access international capital markets tend to use all sources of domestic and foreign funding at their disposal. They have a more marked presence of foreign shareholders, which became a more significant determinant in 2008, and boast better corporate governance scores. Firms without international bank loans may be the most financially constrained among non-financial listed firms.

The next section presents a literature review on the credit crunch in the U.S. repurchase agreements (repo) market and of credit constraints and how this affected emerging markets and companies, the changes in regulatory paradigms after the crisis and their potential effects, as well as a review of the Brazilian related evidence and a brief comparative analysis of Brazilian Eurobond financing before and during the crisis. Third section presents the procedure and model while fourth section offers a descriptive comparative analysis of capital structure indicators of our sample and the analysis of capital structure determinants for a year prior to the global financial crisis and the crisis year of 2008. Final section concludes the article. 


\section{Background and Literature Review}

\section{The financial crisis in the US}

This article will not discuss the details of the financial crisis. Those have been covered by many studies, which include the broad analyses in Acharya and Richardson (2009) and also those collected by the Organization for Economic Cooperation and Development (2009) and by Eichengreen and Baldwin (2008), among others. Bacha and Goldfajn (2009) and O. Barros and Giambiagi (2009) provide a Brazilian view of the crisis. This section will, conversely, present a financial approach to the U.S. banking crisis, placing particular emphasis on the price of assets provided as collateral in repurchase agreements and on the lack of liquidity that resulted from their price decline. Repos correspond to what is known in Brazil as the overnight or the open market and boast an average daily trading volume in the USA of several trillion dollars. This discussion will serve as a background for the analysis of the potential effects of the crisis on Brazilian companies.

Gorton (2009) and Gorton and Metrick (2012) believe that the 2008 global financial crisis was due to a loss of confidence in the U.S. financial system. When this happens, liquidity vanishes. An interesting and alternative approach regarding the dearth of liquidity in the world banking system attributes the generalized lack of confidence in banks to a loss in the value of some of the assets used as collateral in repo transactions. Even though losses have been restricted to some of the assets that served as collateral, the difficulty of identifying problematic assets and the banks that in fact held them led to a generalized run on banks. In this context, a run on banks in the repo market paralyzed the credit market, significantly reducing the ability of companies to obtain financing.

Banks use part of their cash and time deposits to buy bonds. Most of these bonds are safe and risk-free, like the central government bonds of the countries in which they operate. These bonds also included securities backed by very safe mortgages and not quite as safe mortgages, as was later revealed. According to Gorton and Metrick (2009), safe bonds are those whose value does not depend on information and that are not subject to adverse selection. Assets whose value does not depend on obtaining and correctly interpreting information are considered to be information-insensitive. These assets are very liquid and traded without the need for private information and with no losses for insiders. Gorton and Metrick (2009) define liquidity as the ability to trade something quickly, without influencing its price and without the risk of the parties involved facing adverse selection. However, what happens when assets that are information-insensitive become sensitive?

According to Gorton and Metrick (2009), a single sufficiently bad event is able to generate adverse selection. In this situation, assets that are considered to be immune to adverse information and are supposedly risk-free can no longer be regarded as safe. In this situation, it is very important to become the informed party in transactions involving these securities. When this occurs, uncertainty reduces trading volumes and market liquidity. As observed by Ivashina and Scharfstein (2010), despite the global scale of the crisis and its impact on all financial market participants, some banks were more affected than others. Yet, it was impossible for clients to know which counterparties would not honor their debts and, thus, even very safe securities lost value. Although clients could well believe that not all institutions would become insolvent, it was impossible to know which would be the most affected, and consequently a run on the banks took place. Clients withdrew their deposits before it was too late, reducing bank reserves and, consequently, the lending capacity of the financial system. Companies with repo operations backed by securities that were losing value found themselves in a worrisome situation because these securities had become unsafe and no longer provided an assurance that their end of the repo transaction would be fully honored.

Gorton and Metrick (2009) define a haircut as the discount on the price of securities provided as collateral in repo transactions. The haircut is one percent if US\$99 is offered as collateral for the repurchase of a US $\$ 100$ bond. The authors recall that haircuts did not exist before the subprime crisis because repo market agents priced securities based on the assumption that they were immune to 
information. The authors allege that the more risk-sensitive securities originated from real estate transactions began to suffer haircuts after the crisis, including high-quality mortgage-backed securities. Acharya, Gale and Yorulmazer (2011) argue that the financial amount that a security is able to provide when used as collateral depends directly on how the information regarding its quality is revealed. The haircut on some securities reached 100 percent at the end of 2008, indicating that certain assets would not be accepted as collateral at all.

Gorton and Metrick (2009) assert that the combination of a run on the banks and of a reduction in credit available for companies caused by the increase in the haircut created a financing difficulty for the banks. On the one hand, in order to provide collateral for repo operations, banks had to use securities whose total nominal value was progressively becoming greater than the deposits they guaranteed. On the other hand, as the bonds that were purchased with funds from demand and time deposits were losing value, doubts began to arise as to the actual creditworthiness of those deposits. Brunnermeier (2009) and Gorton (2009) affirm that banks had difficulties rolling over their short-term debt due to the concern of their clients about the solvency of the banking system during the crisis. Ivashina and Sharfstein (2010) contend that banks also suffered due the unexpected cutting of their lines of credit. The price of securities went down even further because banks were forced to sell those securities in their portfolios in face of a lack of credit and the need to reduce leverage, worsening the liquidity in the system. Gorton and Metrick (2009) explain that securities in banks' portfolios thus became information sensitive, culminating in a reduction in market liquidity.

Gorton (2009) affirms that the greatest problem in the subprime crisis resided in the fact that nobody imagined that risk was present and so close at hand. Dooley and Hutchison (2009) consider that one of the most impressive characteristics of this crisis lays in the absence of indicators showing that the U.S. economy was on the brink of disaster. They argue that the figures for industrial activity, exports and retail sales did not deteriorate during the period leading up to the Lehman Brothers collapse. We proceed to review the literature about the impact of the credit crunch on emerging markets.

\section{The crisis and emerging markets}

Dooley and Hutchison (2009) believe that the run on the banks that occurred in October 2008 in the U.S. was a determining factor in the paralysis that gripped the U.S. credit market. The consequences of this event had a direct impact on other developed countries' credit markets because their banks also came to have information-sensitive securities in their assets. Emerging markets also suffered with a lack of credit and a decline in economic activity. Dooley and Hutchison (2009) affirm that the imports and exports of many countries fell by approximately 30 percent between September 2008 and January 2009 and that even countries with relatively few ties with the US were affected. The impacts in the Credit Default Swaps (CDS) market, for example, were also felt in emerging countries. The authors highlight that the default of Lehman Brothers affected all countries in a similar fashion, raising CDS spreads. CDS spreads for Brazil, Russia, and South Africa, for example, were hovering below 100 basis points (bps) before the crisis and climbed to the $200 \mathrm{bps}$ level during 2008, jumping to the 400 bps level in 2009, with Russia and Turkey crossing the 800 bps level. In May of 2012 Russia and Turkey are back to the 300 bps level while Brazil and South Africa CDS levels are slightly below 200 bps according to Deutsche Bank Research (http://www.dbresearch.com, retrieved on 2 June 2012). The Lehman Brothers collapse put an end to the belief that emerging markets would escape the effects of the crisis in the U.S.

Dooley and Hutchison (2009) argue that a decoupling between emerging countries and the U.S. did effectively occur before the beginning and even during the first months of the subprime crisis, but that an intense recoupling began to take place starting from August 2008. They assert that the crisis was initially underestimated in emerging markets. Roubini (2009) believed that the whole world would suffer even more with the shrinking of the U.S. economy and that not even emerging markets would remain unscathed. Azevedo and Terra (2009), in contrast, contend that the adoption of a floating exchange rate regime and improvements in economic policies rendered the impacts of this 
financial crisis on the non-financial portion of the Brazilian economy milder than those of the crises of 1990s. Nevertheless, the subprime crisis had a negative impact on emerging countries, at least with respect to their bond prices and returns.

The crisis in Brazil took the form of a liquidity crunch without serious solvency problems, according to the analyses in Bacha and Goldfein (2009) and O. Barros and Giambiagi (2009). Delinquency rates on loans remained close to pre-crisis levels. The most important channels of contagion were the lack of credit, exchange rate devaluation, and more pessimistic expectations conveyed by a crisis of confidence that affected companies and consumers alike. Measures adopted by the National Monetary Council, the ultimate overseer of the Brazilian financial market, and the Brazilian Central Bank (BCB) increased the liquidity in the domestic financial system and sustained credit levels. These measures included incentives for the acquisition of small bank assets by medium and large-sized banks, the reduction of compulsory deposit requirements, and an increase in deposit insurance for deposits of up to $\mathrm{R} \$ 20$ million, in order to provide relief mainly for small and mediumsized banks. Bacha and Goldfein (2009) and O. Barros and Giambiagi (2009) list various additional measures adopted by the government in 2008 and 2009 to mitigate the effects of the crisis. In sum, they included those related to the exchange rate, new rediscounting mechanisms, the reduction of the short-term interest rate, cuts in compulsory deposit requirements, tax reductions, and state-owned bank transactions designed to restore credit flows.

Yet, the crisis affected the performance of the external accounts of Brazil. Comparing end-ofthe-year BCB economic figures immediately before the crisis (2006) to those at the end of the main crisis year (2008) we verified that the current account balance fell dramatically from a surplus of US $\$ 14$ billion in 2006 to a deficit of US $\$ 28$ billion in 2008 , even though exports increased substantially (US $\$ 198$ billion in 2008 against US $\$ 138$ billion in 2006). In the meanwhile, international reserves reached record levels, rising to US $\$ 194$ billion at the end of 2008. The external debt reduction strategy pursued by the Brazilian Treasury since the mid 1990s paid off, which became especially evident during the crisis. The net external debt to exports ratio declined from 0.5 in 2006 to -0.1 in 2008 , while the net external debt to the gross domestic product (GDP) ratio fell from around 7 to -1.8 percent in the same years, also according to the BCB statistics. This increased the level of confidence in the Brazilian economy and Brazil became an investment grade country sometime before the crisis in 2008. The Brazilian country risk, despite increasing in 2008 (428 basis points by the end of the year), was below the Latin American and Asian averages (722 and 574 basis points, respectively). The initial assessment of the impacts of the crisis on Brazil by the government was that it would be negligible, perhaps relying on the significant improvement in international reserves, exports, and the current account balance before the crisis. However, the deterioration in the current account revealed that there was a significant impact, albeit not as strong as in developed countries and some emerging countries. As Dooley and Hutchison (2009) observed, the link with the crisis became stronger after August 2008, lending support to the comparative analysis performed in this article of a year prior relative to a year during the crisis.

\section{Regulation changes}

Helleiner and Pagliari (2010) discuss the influence of the financial crisis on the international regulation of financial markets. According to these authors, international prudential regulations usually evolved as a response to crises. Bank capital adequacy under the Basel agreements led the way to international prudential regulation in 1988. Regulatory coordination also took place regarding securities markets, rating agencies, insurance markets, payment and settlement systems, and on to broader issues such as corporate governance, auditing and accounting standards. They observe that this supranational regulatory framework was fractured throughout a large number of multilateral institutions and had predominantly a non-mandatory nature, with the real lawmaking and supervisory authority over each national financial market remaining under national jurisdictions. Rule makers in most international bodies consisted, by and large, of representatives of the major developed markets and emerging market participation was marginal. Finally, a key characteristic of this phase of the international financial regulatory framework was to let private actors have a significant role in its 
development and supervision. Levine (2012) ads that even public regulators, who are not elected and were largely not monitored and held accountable, failed to act in the public good, bearing some of the responsibility for the crisis by continuously designing and implementing policies that contributed to the financial fragility of the financial system.

The Group of Twenty (G20) first met in 2008 and includes the European Union and 19 other member countries, both developed and developing. It embraced recommendations set out by these same regulatory bodies after the crisis in a major policy setting change relative to the pre-crisis period. Developing countries representatives co-chaired the G20 working groups. Bank regulation was at the center of the reforms, especially regarding risk management, securitized products, liquidity and other prudential rules, as well as executive compensation disclosure rules, reflected in Resolution 3.921 introduced by the Brazilian Central Bank in 2010, for example. Credit rating agencies and their systemic risk influence were also addressed. The global financial governance has been strengthened through the creation of the Financial Stability Board (FSB) that works with the IMF in monitoring cross-border financial risks as well as to nurture and guide the work of international standards setting bodies. The FSB counts upon significant emerging market participation and was provided with much more structure than previous international bodies. This supranational regulatory framework still largely derives from networked forms of governance and is mostly non-binding and very flexible at the national implementation levels. On the other hand, FSB membership requires implementation of the main standards, according to Helleiner and Pagliari (2010). A major change from previous principles is less reliance on market forces and on private parties to make and enforce rules, such as in credit risk management and credit agencies, and greater public overseeing of private rulemaking bodies. However, principles such as fair value accounting, private accounting standards setting, and the fractural nature of international bodies, now with a greater number of members, remain essentially unchallenged, as well as the unaccountability and lack of monitoring of public regulators (Levine, 2012; Zimmermann, 2010).

The Dodd-Frank Wall Street Reform and Consumer Protection Act of 2010 is one of the most well-known and far reaching new pieces of regulation. It touches both U.S. and foreign institutions operating in and with U.S. institutions or trading their securities in the U.S.A., such as Brazilian companies with ADR programs (Tanoue, 2010). It gave more power to regulatory agencies, created systemic risk management power and advance warning entities, required greater transparency from hedge funds and over-the-counter derivatives, increased credit rating agencies supervision and accountability, and introduces whistleblower provisions. The law allows a U.S. shareholder of a Brazilian company, for example, to accuse and potentially put that company under investigation by U.S. authorities. The law also allows for U.S. authorities to prosecute foreign companies for committing fraud in the U.S.A. and substantially harming U.S. citizens, even if their securities do not trade in U.S. markets, such as under an ADR 144A arrangement. Corporate governance provisions of the law also enhance regulation about claw-back provisions on executive compensation, for example. Naturally, financial risk management, capital adequacy, systemic risk, and crisis management are also tackled by the law and may reach the large Brazilian banks operating in the U.S.A. Consumer protection aspects of the law may extend to Brazilian firms issuing securities in the U.S.A. or firms that extend credit to consumers, such as credit card companies. Natural resource companies will have to report about employee health and safety issues and taxes paid to all foreign entities where they operate. Thus, Brazilian firms must be very careful about the validity and accuracy of what they report (Tanoue, 2010). These and other provisions of the law represent additional costs to Brazilian and other emerging market companies and may change their foreign securities issuance patterns in the future.

\section{The crisis and companies}

Companies were affected by the lack of liquidity in the financial system and by the slower economic activity. Naturally, this effect was not uniform. Gorton and Metrick (2009) list various studies that conclude that returns on investment grade corporate bonds behave similarly to government bonds and are sensitive to information about interest rates but not to information about the companies themselves. Yet, speculative-grade corporate bond prices react to changes in share prices and company 
information certainly affects share prices. Acharya et al. (2011) suggest that investor expectations change during moments of crisis because bad rather than good news becomes the norm. In this situation, positive company news are probably less frequent, reducing the value of company assets used as collateral, even if their intrinsic value remains unchanged, making debt rollover more difficult.

The volume of total bank credit granted to Brazilian companies, however, remained above $\mathrm{R} \$ 380$ billion, with a growing and significant volume of loans for working capital and a much lower and stagnant level of longer-term loans for the purchase of goods, according to BCB statistics. On the other hand, foreign credit granted to Brazilian companies took a sharp decline from its peak of $\mathrm{R} \$ 30.6$ billion in November 2008 to $\mathrm{R} \$ 15.2$ billion in August 2009. Bank spreads have risen from below 12 percent a year in the beginning of 2008 to a level of around 18 percent by the end of that year. Spreads have fallen since them.

Campello, Graham, and Harvey (2010) performed a timely study about the impact of the financial crisis on credit-constrained companies in the U.S.A., Europe and Asia. Instead of the usual measures of credit constraints, such as firm size and credit risk classification, they used a declaration from company officers obtained from questionnaires. The authors contend that their metric produces better results, in terms of determining the characteristics of credit-constrained firms, than those employed in seminal studies and that it establishes key differences between credit-constrained and unconstrained companies. Companies that consider themselves as credit constrained, henceforward simply referred to as credit-constrained companies, tend to have a worse credit risk classification, be less profitable, have lower growth rates, and have experienced constraints regarding access to lines of credit more often, whether in terms of cost or volume required. Surprisingly, credit constraints are not a function of company size, despite the frequent use of this latter variable in the literature.

Campello et al. (2010) point out that credit-constrained companies were more likely to sell assets to finance their operations in 2008 than unconstrained companies. They conclude that creditconstrained companies enact deeper cuts in research and development investments, personnel, capital investments, and dividend payments. Fifty percent of financially constrained companies revealed that they had shelved attractive investments. Only one out of five unconstrained firms displayed this behavior. The authors add that credit-constrained firms are not able to implement their investment plans fully because they either have to pay far more for capital or are simply unable to obtain the necessary volume of credit due to their riskier nature. These companies probably resort more often to internally generated capital than their unconstrained counterparts. Ivashina and Scharfstein (2010) emphasize the importance of the bank-firm relationship. Firms that are clients of banks with liquidity problems may find it difficult to obtain loans from other banks with which they do not have a commercial relationship, even if these banks have funds to lend.

In order to assure their liquidity and survival, credit-constrained companies keep a larger percentage of their assets in liquid form and accelerate credit line withdrawals during crises in order to preserve their liquidity (Campello, Graham, \& Harvey, 2010). Credit-constrained companies may make preventive use of their lines of credit, keeping their external capital in reserve, in case they face problems renewing them. This behavior was not observed among unconstrained companies. During the crisis, there was a significant decline in the volume of credit-constrained company reserves because the companies used them to finance investments and operations. The reserves of unconstrained firms remained stable. More than half the companies studied stated that they would opt to use their reserves to develop attractive projects if they could not obtain new financing, while 40 percent would simply consume their reserves in current operations. The authors point out that abandoning investments with a positive net present value reduces the speed of recovery in the economy.

\section{Brazilian literature on credit constraints}

Many non-financial Brazilian listed firms may be financially constrained. The financial crisis led to a credit crunch. Thus, it is reasonable to expect that financially constrained firms were hit 
harder. Crisóstomo (2009) suggests that Brazilian companies face credit constraints because their investment in innovation is unstable and they used internally generated funds extensively in the 19952006 period. Terra (2003) concludes that Brazilian companies were credit constrained in the 19871997 period, with the notable exception of larger and multinational firms in the latter portion of her sampled years. Kalatzis and Azzoni (2009) affirm that capital-intensive Brazilian firms, in particular, face greater financial constraints in volatile times by means of a sample from the same time period used by Terra (2003). Costa, Paz and Funchal (2008) conclude that Brazilian firms that issued ADRs are not financially constrained for a 1995-2007 sample. Portal, Zani and Silva (2012) conclude that external financing by constrained companies is less sensitive to cash flow generation while internal financing is quite sensitive to it for a sample in the 1995-2005 period. The same is not observed for unconstrained companies. Finally, an unpublished paper by Kirch, Terra and Procianoy (2010) concedes that investment by unconstrained companies is not affected by the way they obtain financing. Investment of constrained firms, conversely, is sensitive to the availability of internal funds. These authors also suggest that industry is important to identify unconstrained firms.

Lima, Assaf, Perera, and Silva (2011) examine how the domestic inflation, interest and exchange rates related to debt levels of 83 Brazilian public companies in the 1995-2007 period. They find that in the periods of greater uncertainty, such as around the floatation of the real and the Lula da Silva election, total corporate debt levels indicators rose with exchange rates and with interest rates in simple regression models. They used four measures of debt levels and only those based on total debt levels showed a significant relationship with the exchange rate and with the interest rate. Total debt indicators include short and long-term debt, as well as foreign and domestic currency debt. Thus, the rise of debt levels, particularly during more volatile periods, may be due to the use of more short-term debt or foreign currency debt, or a combination of those. Their multiple regression models are hard to interpret because the three independent variables are correlated and affect each other. Thus, their results suggest that exchange rates may be positively related to debt levels, which hints that many of the sampled companies display foreign currency debt and/or seek more short-term debt in difficult times. There is a survivorship bias in their analysis because the authors employed only those companies with data for the entire 1995-2007 period, certainly favoring those that are larger and more successful, which are supposedly the ones with easier access to financing. Finally, the authors find that relative debt levels increase while the domestic interest rate decreases, which is what one should expect.

We computed the correlation between the year-end Brazilian real value of the U.S. dollar and net Eurobond issues figures obtained from the BCB and the BIS, respectively, between 1995 and 2008 as -0.46 , statistically significant at the one percent level. Companies tend to issue bonds abroad when the Brazilian real appreciates relative to the dollar and foreign exchange rate volatility is low. However, when the local currency depreciates and volatility increases, they tend not to roll their bonds over, generating net negative issues. Thus, the increase in total debt levels verified by Lima et al. (2011) when the U.S. dollar appreciates is probably due to a combination of increased short-term domestic borrowing and an appreciation of foreign currency debt values.

The evidence for Brazilian firms seems to confirm that in times of crisis financially constrained firms suffer the most and seek more short-term domestic debt and that larger firms with foreign owners and ADR programs are not financially constrained, particularly those in industries where collateral assets are plentiful.

Our first four hypotheses are derived from the credit constraints discussion in the previous sections:

H1: Larger, and possibly less credit-constrained firms, have more access to all sources of international financing: bank loans, Eurobonds, and ADRs;

H2: Firms with no access to international bank loan financing, the most basic type of international financing, may be more credit-constrained, and use fewer external financing sources, both domestic and foreign, and possibly more internally generated funds; 
H3: Brazilian non-financial listed firms, if they are mostly credit-constrained, will display a greater use of short-term financing, particularly from banks, in the crisis year;

H4: Brazilian non-financial listed firms, if they are mostly credit-constrained, will display a greater use of domestic financing sources in the crisis year because they may have more established relationships with banks operating in Brazil.

\section{Determinants of capital structure}

L. A. B. C. Barros and Silveira (2008) offer a recent analysis of the determinants of the capital structure of Brazilian companies and also review previous Brazilian studies. Leal (2008) provides a survey of the capital structure literature with a focus on Brazil and emerging markets. Frank and Goyal (2008) present a comprehensive survey of theoretical and empirical issues of this subject. The Brazilian articles and the literature therein suggest that Brazilian firms use more bank debt than debt securities issuance. Naturally, the role of domestic banks is important and, regarding long-term debt, the National Bank for Economic and Social Development (BNDES) cannot be overlooked as the main long-term lender in the country.

There are some variables that are usually present and significant in studies of determinants of capital structure, which were labeled as the "reliable leverage factors" in the literature review by Frank and Goyal (2008, p. 176). Tangible assets are common debt collaterals and are not easily replaced by high-risk assets, and asset tangibility's $(T)$ relationship with leverage is reliably positive because the more tangible assets a firm has the greater its collateralization ability (Frank \& Goyal, 2008). Larger firms may be more diversified, have greater longevity and a better reputation in the debt market and thus present lower default risk and, thus, Frank and Goyal (2008) report that the relationship between company size $(S)$ and leverage is reliably positive. More profitable firms obviously generate more funds to invest and profitability ( $R O A)$ is usually negatively associated to leverage because firms prefer to use internally generated funds to debt according to the Pecking Order Theory (Campello et al., 2010; Frank \& Goyal, 2008). Company growth potential usually maintains a negative relationship with debt because it may be easier for insiders to increase project risk at the expense of overlooking debt holders, increasing the cost of debt (Frank \& Goyal, 2008). Growth potential has been represented by Tobin's $\mathrm{Q}(Q)$, which is a common proxy for it. The Appendix presents our operational definitions for these variables.

L. A. B. C. Barros and Silveira (2008) employed some additional variables. Volatility (V) may be positively related to an increase in market value debt ratios because market values may decrease in periods of greater stock market volatility. The score of a corporate governance index $(C G I)$ created and described in Leal and Carvalhal-da-Silva (2007a), which is greater when companies adopt better transparency and corporate governance practices and, consequently, borrowing for them should be easier, as is supported by the Brazilian evidence presented by Leal and Carvalhal-da-Silva (2007a) and L. A. B. C. Barros and Silveira (2008).

We included two more variables to account for the international exposure of companies because our dependent variables are relative measures of international financing sources: exports $(E)$ and foreign shareholder $(F)$. We expect that exporting companies and those with relevant foreign shareholders could more easily access the international financial market and, thus, present greater international debt ratios.

These variables will be present in our model of the determinants of the international components of capital structure and two additional hypotheses are derived from their role in the models:

H5: Firms tangibility, size, stock price volatility, corporate governance practices, export activity, and foreign shareholding will be positively related to their use of all international debt financing, while ROA and Q may be negatively related to international debt financing; 
H6: Firms that export, display better corporate governance practices or foreign shareholding will use all sources of international financing more.

Finally, putting together the discussions about credit constraints and the determinants of the international components of capital structure of Brazilian non-financial firm, we see no reason to believe that these determinants would change with the crisis, hence our last hypothesis:

H7: International financing is used more often by the larger and less credit-constrained firms and thus its determinants will not change in the crisis year.

\section{Eurobond financing in Brazil compared to other countries}

Usage of the international bond market by Brazilian companies was remarkably low considering the high domestic borrowing costs. Statistics computed by the Bank of International Settlements (BIS) reveal that Eurobond issues by non-financial Brazilian companies were merely about 1.2 percent of Brazil's gross domestic product (GDP) by the end of 2008, down from about 1.5 percent in 2006 . These figures are comparable to the average for Asian countries, while Eurobond issues amounted to about 4.8 percent of GDP for developed countries in 2006 and increased to about 5 percent of GDP by the end of 2008. The average figures for Latin American countries are more than twice of those of Brazil, as are those of some emerging market countries with greater country risk spreads, such as the Philippines (3.5 percent of GDP) and South Africa (2.4 percent of GDP).

Emerging markets in Latin America and Asia displayed a notable increase in liquidity and reserves before the crisis. We obtained the international liquidity for developed countries as the sum of portfolio investments and financial derivatives and other investment items from the International Financial Statistics (IFS) database of the International Monetary Fund (IMF). The international crisis led to a significant reduction in international liquidity, which declined from US\$8.5 trillion in 2006 (US\$10 trillion in 2007) to US\$6.5 trillion in 2008, consistent with our recount of the financial crisis in previous sections. However, emerging Latin American and Asian countries' international reserves increased substantially from US $\$ 2$ trillion in 2006 to US $\$ 3$ trillion in 2008, also according to figures obtained from the IFS and our own computations.

Brazilian companies' reluctance to issue abroad may be related to the availability of hedging and to foreign exchange risk. The supply of foreign currency hedge varies according to the volatility of the nominal exchange rate. In periods of high volatility (2002 and 2008, for example), the BCB significantly increased its provision of foreign exchange hedging. The amount of foreign exchange hedging provided by the BCB rose dramatically in 2008 as well, when the exchange rate underwent a sharp devaluation. Brazilian companies use currency swaps and Non-Deliverable Forwards (NDFs) as their main hedging means. The consolidated notional value under custody of the two types of contracts, as expected, increased significantly during the crisis. We obtained figures from CETIP, a company that acts as a Brazilian market integrator, offering registration, custody, trading, and settlement of securities and assets. Currency swap ( $\mathrm{R} \$ 107$ billion in 2006 and $\mathrm{R} \$ 116$ billion in 2008) and NDF (R $\$ 32$ billion in 2006 and $\mathrm{R} \$ 99$ billion in 2008) amounts registered at CETIP increased substantially from 2006 to 2008 .

\section{Procedure}

We chose 2004 to represent the pre-crisis financing structure because it was sufficiently distant from the beginning of the crisis and to compare our results with those of Leal and Carvalhal-da-Silva (2007b). We decided to examine the year-end information for 2008 as this was the most severe year of the crisis, as markets partially recovered in 2009 and 2010, despite all the difficulties still lingering in the US and Europe. 
We investigated which types of companies raise more funds in the international market by means of bank loans, Eurobonds, and ADRs, before and during the crisis through a descriptive comparative analysis of firm characteristics and financial indicators for each category. The tests include a comparison of selected indicators for 2004 and 2008 and for firms with and without international bank, Eurobons, and ADR financing. We also estimated probit models for companies listed at the Bolsa de Valores, Mercadorias e Futuros (BM\&FBovespa) in 2004 and 2008 with three dependent variables related to aforementioned international financing choices. We computed robust standard errors to correct for heteroskedasticity and correlation and also tested for multicollinearity, with the variance inflation factor lower than 10 for all variables. We ran the models for 2004 and 2008 separately. The Appendix presents a list, description and computation method for each variable. The variables and the hypotheses were discussed in sections Brazilian Literature on Credit Constraints and Determinants of Capital Structure.

Our model may be represented by Equation 1 where the dependent variable $\left(D_{i}\right)$ is one of the international financing dummies (Intbanks, Eurobonds, and $A D R s$ ), and the explanatory variables are tangibility $(T)$, size $(S), R O A$, Tobin's Q $(Q)$, volatility $(V)$, the $C G I$ and the export $(E)$ and foreign shareholder $(F)$ dummies, as defined above, and $a_{i}, b_{i}$, and $\varepsilon_{i}$ are the intercept, the coefficients of each explanatory variable, and the error term for firm $i$. The expected signs of each coefficient are collected in Table 4.

$$
D_{i}=a_{i}+b_{1} T+b_{2} S+b_{3} R O A+b_{4} Q+b_{5} V+b_{6} C G I+b_{7} E+b_{8} F+\varepsilon_{i}
$$

Table 1 shows the industry distribution of the sample according to international financing sources. As expected, companies from industries that include very large companies, with substantial tangible assets in place, such as telecommunications, electricity, food, steel, metallurgy, and textiles, frequently tap international markets for finance. These results are consistent with those of Kirch et al. (2010), who advocate that industry is an important factor to discern constrained from unconstrained companies, and with our $\mathrm{H} 5$ hypothesis about asset tangibility and size.

Table 1

Number of Non-Financial Brazilian Listed Companies with Access to the International Financing by Industry in 2008

\begin{tabular}{lcccccccc}
\hline \multirow{2}{*}{ Sector } & \multicolumn{2}{c}{ No. Comp. } & \multicolumn{2}{c}{ International Banks } & \multicolumn{2}{c}{ Eurobonds } & \multicolumn{2}{c}{ ADRs } \\
\cline { 2 - 9 } & $\mathbf{2 0 0 4}$ & $\mathbf{2 0 0 8}$ & W/O & With & W/O & With & W/O & With \\
\hline Electricity & 33 & 39 & 19 & 20 & 29 & 10 & 27 & 12 \\
Other & 26 & 47 & 31 & 16 & 42 & 5 & 32 & 14 \\
Steel and metallurgy & 16 & 21 & 6 & 15 & 17 & 4 & 16 & 5 \\
Textiles & 16 & 20 & 9 & 11 & 19 & 1 & 18 & 2 \\
Food and beverage & 9 & 13 & 3 & 10 & 6 & 7 & 9 & 4 \\
Telecommunications & 21 & 13 & 3 & 10 & 6 & 8 & 4 & 10 \\
Motor vehicles and parts & 7 & 11 & 2 & 9 & 10 & 0 & 9 & 2 \\
Chemicals & 15 & 11 & 3 & 8 & 8 & 3 & 9 & 2 \\
Transportation services & 2 & 10 & 4 & 6 & 7 & 3 & 4 & 6 \\
Pulp and paper & 7 & 6 & 2 & 4 & 4 & 2 & 3 & 3 \\
Construction & 6 & 26 & 23 & 3 & 24 & 2 & 16 & 10 \\
Agriculture and fishing & 5 & 4 & 1 & 3 & 4 & 0 & 4 & 0 \\
\hline
\end{tabular}


Table 1 (continued)

\begin{tabular}{lcccccccc}
\hline \multirow{2}{*}{ Sector } & \multicolumn{2}{c}{ No. Comp. } & \multicolumn{2}{c}{ International Banks } & \multicolumn{2}{c}{ Eurobonds } & \multicolumn{3}{c}{ ADRs } \\
\cline { 2 - 9 } & $\mathbf{2 0 0 4}$ & $\mathbf{2 0 0 8}$ & W/O & With & W/O & With & W/O & With \\
\hline Industrial machinery & 5 & 4 & 1 & 3 & 4 & 0 & 4 & 0 \\
Oil and gas & 7 & 3 & 0 & 3 & 2 & 1 & 2 & 1 \\
Mining & 3 & 2 & 0 & 2 & 1 & 1 & 1 & 1 \\
Commerce & 5 & 7 & 6 & 1 & 7 & 0 & 5 & 2 \\
Electrical and electronics & 7 & 5 & 4 & 1 & 5 & 0 & 5 & 0 \\
Insurance & 1 & 3 & 3 & 0 & 2 & 1 & 3 & 0 \\
Non-metallic minerals & 1 & 1 & 1 & 0 & 1 & 0 & 1 & 0 \\
\hline Number of companies & 192 & 246 & 121 & 125 & 198 & 48 & 172 & 74 \\
\hline
\end{tabular}

Note. Sectors ordered according to the number of companies with international bank loans. W/O means without. Source: data from Economatica - Tools for Investment Analysis (n.d.). Base de dados. Sao Paulo: Author, the Comissão de Valores Mobiliários (n.d.). Informações sobre as Companhias Abertas. Retrieved October, 2009, from http://www.cvm.gov.br, and author calculations.

\section{Empirical Findings}

Table 2 shows capital structure indicators, types of financing, and the financial costs of nonfinancial Brazilian listed companies before the crisis (2004) and during the crisis (2008). We performed statistical tests to evaluate if there were significant changes (in means and proportions) of capital structure indicators from 2004 to 2008. We analyzed all companies with available data in 2004 and 2008 (192 and 246 firms, respectively). As a robustness check, we also evaluated the same companies in both years (128 firms) to check if our results could be due to sample changes from 2004 to 2008. Overall the results were similar using unbalanced and balanced panels.

In general, capital structures remained stable, with liabilities accounting for 59 percent of total assets. Short-term financing fell from 11.16 to 9.69 percent of total assets, while long-term financing increased from 13.29 to 18.15 percent of total assets. The decline in short-term financing and the increase in long-term financing are statistically significant at $10 \%$ and $1 \%$, respectively. This comparison does not confirm the evidence of previous related works, such as Lima et al. (2011), as well as our $\mathrm{H} 3$ hypothesis. 
Table 2

Average Capital Structure and Financial Indicators of Non-Financial Listed Brazilian Companies before and during the Crisis of 2008

\begin{tabular}{|c|c|c|c|c|c|c|c|c|}
\hline \multirow[t]{2}{*}{ Indicators } & \multicolumn{4}{|c|}{$\begin{array}{l}\text { Unbalanced Panel } \\
\text { Companies with Available Data }\end{array}$} & \multicolumn{4}{|c|}{$\begin{array}{c}\text { Balanced Panel } \\
\text { Same Companies in } 2004 \text { and } \\
2008 \\
\end{array}$} \\
\hline & 2004 & 2008 & Change & $\mathbf{p}$ & 2004 & 2008 & Change & $\mathbf{p}$ \\
\hline Number of Firms & 192 & 246 & 28.13 & NA & 128 & 128 & 0.00 & NA \\
\hline Total Assets (TA, R\$ billion) & 5,04 & 7,17 & 42.26 & 0,29 & 6,52 & 11,34 & 73.93 & 0,15 \\
\hline \multicolumn{9}{|l|}{ Capital Structure } \\
\hline Liabilities/TA (\%) & 58,14 & 59,48 & 2.30 & 0,48 & 57,13 & 59,04 & 3.34 & 0,20 \\
\hline Financing/TA (\%) & 24,45 & 27,84 & 13.87 & 0,02 & 24,14 & 28,56 & 18.31 & 0,01 \\
\hline Short-term financing/TA (\%) & 11,16 & 9,69 & -13.17 & 0,08 & 10,08 & 9,89 & -1.88 & 0,21 \\
\hline Long-term financing/TA (\%) & 13,29 & 18,15 & 36.57 & 0,00 & 14,06 & 20,67 & 47.01 & 0,00 \\
\hline \multicolumn{9}{|l|}{ Types of financing } \\
\hline Domestic bank loans/TA (\%) & 16,62 & 14,92 & -10.23 & 0,16 & 16,67 & 15,30 & -8.22 & 0,17 \\
\hline Domestic bonds/TA (\%) & 2,44 & 5,43 & 122.54 & 0,00 & 2,49 & 5,18 & 108.03 & 0,00 \\
\hline International bank loans/TA (\%) & 7,83 & 5,23 & -33.21 & 0,00 & 7,47 & 5,10 & -31.73 & 0,00 \\
\hline Eurobonds/TA (\%) & 1,29 & 1,53 & 18.60 & 0,57 & 1,42 & 1,52 & 7.04 & 0,86 \\
\hline \multicolumn{9}{|l|}{ Share of international financing } \\
\hline$\%$ of firms with foreign banks & 70,83 & 50,81 & -28.26 & 0,00 & 71,88 & 57,19 & -20.44 & 0,00 \\
\hline$\%$ of firms with Eurobonds & 19,27 & 19,51 & 1.25 & 0,95 & 21,88 & 24,22 & 10.69 & 0,66 \\
\hline$\%$ of firms with ADRs & 28,65 & 30,08 & 4.99 & 0,74 & 33,59 & 33,59 & 0.00 & 1,00 \\
\hline \multicolumn{9}{|l|}{ Financial costs } \\
\hline Financial expenses/financing (\%) & 30,46 & 31,79 & 4.37 & 0,68 & 29,21 & 27,27 & -6.64 & 0,46 \\
\hline \multicolumn{9}{|l|}{ Other } \\
\hline Return on assets - ROA (\%) & 7,06 & 3,62 & -48.73 & 0,00 & 7,08 & 4,24 & -40.11 & 0,00 \\
\hline Tobin's Q & 2,97 & 1,06 & -64.31 & 0,00 & 3,03 & 1,11 & -63.37 & 0,00 \\
\hline Fixed Assets/TA (\%) & 46,07 & 33,56 & -27.15 & 0,00 & 46,89 & 38,84 & -17.17 & 0,00 \\
\hline $\begin{array}{l}\text { Voting shares largest shareholder } \\
(\%)\end{array}$ & 63,64 & 54,32 & -14.64 & 0,00 & 63,64 & 59,60 & -6.35 & 0,25 \\
\hline Total shares largest shareholder (\%) & 47,57 & 45,84 & -3.64 & 0,47 & 45,68 & 42,86 & -6.17 & 0,50 \\
\hline Corporate governance index & 7,53 & 12,88 & 71.05 & 0,00 & 7,86 & 11,35 & 44.40 & 0,00 \\
\hline Annualized volatility (\%) & 67,44 & 61,52 & -8.78 & 0,08 & 64,09 & 55,40 & -13.56 & 0,04 \\
\hline$\%$ of exporting firms & 52,05 & 48,78 & -6.28 & 0,55 & 49,52 & 50,00 & 0.97 & 0,94 \\
\hline$\%$ of firms with foreign shareholders & 42,71 & 67,41 & 57.83 & 0,00 & 38,28 & 51,56 & 34.69 & 0,03 \\
\hline
\end{tabular}

Note. Data from Economatica - Tools for Investment Analysis (n.d.). Base de dados. Sao Paulo: Author, the Comissão de Valores Mobiliários (n.d.). Informações sobre as Companhias Abertas. Retrieved October, 2009, from http://www.cvm.gov.br, and author calculations; Change is the percent change between 2004 and 2008; $\mathbf{p}$ is the p-value of a difference t-test between 2008 and 2004 averages. 
There was a decline in bank loans relative to total assets (both domestic and international) and an increase in debt securities (domestic bonds and Eurobonds) relative to total assets. The increase of domestic bonds and the decline of international bank loans are statistically significant at $1 \%$. The increase in the use of domestic bonds is supportive of our $\mathrm{H} 4$ hypothesis about the greater use of domestic financing sources in the crisis year. There was a significant decline in the percentage of companies with international bank loans and a slight increase (but not statistically significant) in the percentage of firms issuing Eurobonds and ADRs. The financial expenditures of companies increased during the crisis, as expected, but the results are not statistically significant. These results suggest that bank loans were partially replaced by bond issues. Our recount of the crisis impacts in previous sections revealed that international financing became more expensive and scarce for Brazilian companies during the crisis.

Average profits (ROA) and the relative market value (Tobin's Q) of companies were much lower in 2008 than in 2004. The decrease of ROA and Tobin's Q is significant in both statistical and economical terms, maybe as a consequence of the financial crisis and the ensuing decrease in stock market values, as reported in Azevedo and Terra (2009). Corporate governance scores significantly improved during this period and the concentration of equity capital in the hands of controlling shareholders decreased. This last trend has been documented by Silveira, Leal, Barros, and Carvalhalda-Silva (2009) and Sternberg, Leal, and Bortolon (2011) and stems from the new listings at the premium listing levels of BM\&FBovespa, which require more in terms of corporate governance and shareholder rights. Leal (2010) and Silveira et al. (2009) provide more details about these premiumlisting levels.

Table 3 shows capital structure indicators, types of financing, and the financial costs of companies according to their use or not of international financing by the end of 2008. As expected, larger companies with significantly more tangible assets have greater access to all modes of international financing considered, in accordance with our H1 hypothesis. Moreover, companies that finance abroad employ more debt financing and use more long-term debt. These results are similar to those obtained by Leal and Carvalhal-da-Silva (2007b) before the crisis and are consistent with the findings of Terra (2003), Kalatzis and Azzoni (2009), and Costa et al. (2008).

Table 3

Average Capital Structure, Types of Borrowing, and Financial Costs Indicators of NonFinancial Brazilian Listed Companies According to their International Financing Sources in 2008

\begin{tabular}{lrrrrrr}
\hline \multirow{2}{*}{ Indicators } & \multicolumn{2}{c}{ International Banks } & \multicolumn{2}{c}{ Eurobonds } & \multicolumn{2}{c}{ ADRs } \\
\cline { 2 - 8 } & W/O & With & W/O & With & W/O & With \\
\hline Total assets (TA in R\$ Billion) & 2,43 & $11,77^{* *}$ & 3,04 & $24,24^{* *}$ & 2,13 & $18,90^{* *}$ \\
Number of Companies & 121 & 125 & 198 & 48 & 172 & 74 \\
Capital Structure & & & & & & \\
Liabilities/TA (\%) & 53,15 & $65,61^{* *}$ & 57,52 & $67,55^{* *}$ & 59,33 & 59,81 \\
Financing/TA (\%) & 19,31 & $34,66^{* *}$ & 25,66 & $33,07^{* *}$ & 27,07 & 27,20 \\
Short-term financing/TA (\%) & 7,63 & $11,19^{* *}$ & 9,71 & $8,35^{*}$ & 10,41 & $7,19^{* *}$ \\
Long-term financing/TA (\%) & 11,68 & $23,47^{* *}$ & 15,96 & $24,73^{* *}$ & 16,66 & $20,02^{* *}$ \\
Types of Financing & & & & & & \\
Domestic bank loans/TA (\%) & 13,30 & $16,48^{* *}$ & 15,77 & $11,37^{* *}$ & 15,98 & $12,43^{* *}$ \\
Domestic bonds/TA (\%) & 4,84 & 6,01 & 5,08 & $6,89^{*}$ & 5,17 & 6,06 \\
International bank loans/TA (\%) & 0,00 & $10,29^{* *}$ & 4,63 & $7,69^{* *}$ & 0,87 & $3,05^{* *}$ \\
\hline
\end{tabular}


Table 3 (continued)

\begin{tabular}{|c|c|c|c|c|c|c|}
\hline \multirow{2}{*}{ Indicators } & \multicolumn{2}{|c|}{ International Banks } & \multicolumn{2}{|c|}{ Eurobonds } & \multicolumn{2}{|c|}{ ADRs } \\
\hline & $\mathrm{W} / \mathbf{O}$ & With & $\mathrm{W} / \mathbf{O}$ & With & $\mathrm{W} / \mathrm{O}$ & With \\
\hline Eurobonds/TA (\%) & 0,63 & $2,39 * *$ & 0,00 & $7,82 * *$ & 5,09 & 5,57 \\
\hline \multicolumn{7}{|l|}{ Financial Costs } \\
\hline Financial expenses/financing (\%) & 33,45 & 30,31 & 29,38 & 31,31 & 31,77 & 31,84 \\
\hline \multicolumn{7}{|l|}{ Others } \\
\hline Return on assets - ROA (\%) & 4,46 & $2,80 * *$ & 4,15 & $1,42 * *$ & 3,68 & 3,46 \\
\hline Tobin's Q & 1,00 & $1,11 * *$ & 1,04 & $1,12^{*}$ & 1,05 & 1,08 \\
\hline Fixed assets/TA (\%) & 27,76 & $39,18 * *$ & 32,21 & $39,15 * *$ & 32,19 & $36,75^{*}$ \\
\hline Voting shares largest shareholder (\%) & 51,41 & $57,09 *$ & 53,99 & 55,65 & 55,51 & 51,66 \\
\hline Total shares largest shareholder (\%) & 44,80 & 46,82 & 46,41 & 43,55 & 48,01 & $40,97 * *$ \\
\hline Corporate governance index & 13,44 & $12,34 * *$ & 12,65 & $13,85 * *$ & 11,88 & $15,22 * *$ \\
\hline Annualized volatility (\%) & 64,16 & $59,20 * *$ & 61,65 & 61,07 & 60,66 & 63,07 \\
\hline$\%$ of exporting firms & 34,34 & $62,26 * *$ & 48,75 & 48,89 & 52,94 & $40,58 * *$ \\
\hline$\%$ of firms with foreign shareholders & 73,33 & $62,18 * *$ & 61,93 & $87,50 * *$ & 51,33 & $100,00 * *$ \\
\hline
\end{tabular}

Note. Data from Economatica - Tools for Investment Analysis (n.d.). Base de dados. Sao Paulo: Author, the Comissão de Valores Mobiliários (n.d.). Informações sobre as Companhias Abertas. Retrieved October, 2009, from http://www.cvm.gov.br, and author calculations.

* and ** indicate statistically significant differences at the 10 and 5 percent levels, respectively. W/O means without.

Campello et al. (2010) contend that companies' abilities to borrow without credit constraints was not significantly affected by the crisis. The larger companies in our sample could reasonably be described as such, as our results and those of Terra (2003) and Costa et al. (2008), suggest. Firms that raise bank loans abroad exhibit greater leverage, have lower financial costs, and enter into longer-term financing more often than companies that have not taken out foreign bank loans. In general, the former are large companies that have access to other financing sources, such as domestic bonds, Eurobonds, and ADRs. This result is supportive of our $\mathrm{H} 2$ hypothesis.

Firms with international debt, either bank loans or Eurobonds, displayed a smaller ROA than other firms. Many are exporters and their revenues and expenses were certainly affected by the appreciation of the U.S. dollar in Brazil in 2008, a consequence of capital outflows. Table 3 shows that firms that issue Eurobonds also use the whole range of financing sources available to them because they tend to issue domestic bonds as well as to borrow from banks abroad more. Current liabilities finance 67.55 percent of the assets of companies that issue Eurobonds, as opposed to 57.52 percent in the case of those that do not. More than 87 percent of companies that issue Eurobonds have foreign shareholders and exhibit significantly better corporate governance practices, consistent with our H6 hypothesis. It is also possible that companies that do not issue Eurobonds are amongst those that face more credit constraints.

Firms with ADRs use more long-term financing, use less domestic loans and more international bank loans. It is noteworthy that companies that issue securities abroad, both bonds and ADRs, use less domestic bank loans, have foreign shareholders more often, exhibit higher corporate governance scores, present a more dispersed ownership structure, and employ more tangible assets, once again consistent with our H5 and H6 hypotheses. These results suggest that these firms may be less financially constrained, also indicated by Costa et al. (2008). In contrast, firms that use international bank loans present fewer foreign shareholders and lower corporate governance scores but tend to be exporters. Exporting firms' behavior is not consistent with our H6 hypothesis predicting that they would use all sources of international financing more. Maybe exporting firms do not need to use 
international capital markets as much, given their ability to use the export cash flow as collateral for international bank loans.

Finally, firms without Eurobond debt and ADRs use domestic bank loans significantly more, but firms without international bank loans use all sources of financing less, which indicates that the absence of international bank loans may identify the most financially constrained firms among Brazilian non-financial listed companies, in accordance with our H2 hypothesis. International bank loans may be the most common first step for international financing because very few companies without international bank loans display Eurobonds, but the opposite is not true.

Table 4 shows that results of the regression models for 2004 are similar to those for 2008. The probit coefficients in Table 4 are also consistent with those obtained by L. A. B. C. Barros and Silveira (2008) who employed the System General Method of Moments (GMM-Sys). Our H7 hypothesis stated that international financing sources are more often used by less credit-constrained firms and, thus, their determinants should not have changed between 2004 and 2008. Companies with more tangible assets tend to use international bank loans more. There is a positive and significant relation between size and all forms of international financing (bank loans, Eurobonds, and ADRs). Larger firms have greater access to international debt and equity markets. According to Campello et al. (2010), firm size is commonly used as a proxy for credit constraint and the results in Table 4 suggest that larger firms face less credit constraints, as Terra (2003) and Costa et al. (2008) have also pointed out.

Table 4

Determinants of International Financing by Non-Financial Brazilian Listed Companies

\begin{tabular}{|c|c|c|c|c|c|c|c|}
\hline \multirow{2}{*}{ Variable } & \multirow{2}{*}{$\begin{array}{l}\text { Expected } \\
\text { Sign }\end{array}$} & \multicolumn{3}{|c|}{2004} & \multicolumn{3}{|c|}{2008} \\
\hline & & IntBanks & Eurobonds & ADRs & IntBanks & Eurobonds & ADR \\
\hline \multirow[t]{2}{*}{ Tangibility } & + & $0,01 *$ & $-0,01 * *$ & $0,01 *$ & $0,01 * *$ & 0,01 & 0,00 \\
\hline & & $(0,06)$ & $(0,02)$ & $(0,10)$ & $(0,05)$ & $(0,76)$ & $(0,55)$ \\
\hline \multirow[t]{2}{*}{ Size } & + & $0,04 * *$ & $0,08 * *$ & $0,03 * *$ & $0,05 * *$ & $0,03 * *$ & $0,04 * *$ \\
\hline & & $(0,02)$ & $(0,04)$ & $(0,03)$ & $(0,00)$ & $(0,04)$ & $(0,00)$ \\
\hline \multirow[t]{2}{*}{ ROA } & - & 0,00 & $-0,01 * *$ & $-0,01$ & $-0,01 *$ & $-0,02 * *$ & $-0,01$ \\
\hline & & $(0,85)$ & $(0,04)$ & $(0,66)$ & $(0,08)$ & $(0,00)$ & $(0,19)$ \\
\hline \multirow[t]{2}{*}{ Volatility } & - & $-0,01$ & 0,00 & $-0,01 * * *$ & $-0,01 *$ & 0,00 & $-0,01^{*}$ \\
\hline & & $(0,56)$ & $(0,12)$ & $(0,00)$ & $(0,10)$ & $(0,30)$ & $(0,06)$ \\
\hline \multirow[t]{2}{*}{ Tobin's Q } & - & 0,04 & $-0,11$ & 0,08 & 0,18 & 0,02 & $-0,11$ \\
\hline & & $(0,29)$ & $(0,11)$ & $(0,27)$ & $(0,14)$ & $(0,90)$ & $(0,35)$ \\
\hline \multirow[t]{2}{*}{ CGI } & + & 0,00 & $0,60 * *$ & $0,09 * *$ & $-0,03 * *$ & $0,80 * *$ & $0,04 * *$ \\
\hline & & $(0,96)$ & $(0,03)$ & $(0,02)$ & $(0,00)$ & $(0,00)$ & $(0,04)$ \\
\hline \multirow[t]{2}{*}{ Exports } & + & $0,15^{*}$ & 0,04 & $-0,10$ & $0,33 * *$ & 0,02 & $-0,08$ \\
\hline & & $(0,10)$ & $(0,81)$ & $(0,52)$ & $(0,00)$ & $(0,76)$ & $(0,31)$ \\
\hline \multirow[t]{2}{*}{ Foreign shareholders } & + & 0,11 & $0,04 *$ & 0,01 & $-0,02$ & $0,22 * *$ & $0,43^{* *}$ \\
\hline & & $(0,25)$ & $(0,07)$ & $(0,92)$ & $(0,83)$ & $(0,01)$ & $(0,00)$ \\
\hline No. of observations & & 192 & 192 & 192 & 246 & 246 & 246 \\
\hline $\mathrm{R}^{2}$ & & 0,09 & 0,12 & 0,29 & 0,29 & 0,14 & 0,21 \\
\hline
\end{tabular}

Note. Probit regressions models for companies listed at BM\&FBovespa. The models were run for 2004 and 2008 separately and using three dependent variables related to international financing. All variables defined in the Appendix. Robust standard errors were computed to correct for heteroskedasticity and correlation and all $p$-values are in parenthesis. Sources: Economatica Tools for Investment Analysis (n.d.). Base de dados. São Paulo: Author, the Comissão de Valores Mobiliários (n.d.). Informações sobre as Companhias Abertas. Retrieved October, 2009, from http://www.cvm.gov.br, and author calculations. * and ** indicate statistically significant differences at the 10 and 5 percent levels, respectively. 
More profitable companies tend to use less foreign debt, both bank loans and Eurobonds. This result is consistent with the idea that profitable companies are able to retain part of their profits to finance their operations, especially when the cost of credit is high. This is consistent with the Brazilian evidence in Portal et al. (2012), for example. Campello et al. (2010) affirm that credit-constrained companies use more internal capital and try to remain more liquid, reducing their liquidity and dividend payments during periods when credit is scarcer, in order to try to maintain their level of investments. Volatility is inversely related to the issuance of ADRs; that is, companies with ADRs present a lower level of total risk. The quality of corporate governance practices and the presence of foreign shareholders are positively related to usage of capital market financing (Eurobonds and ADRs).

There was a positive association between exports and financing through international bank loans. Curiously, no relationship was found between exports and Eurobond and ADR financing. A possible explanation is that exporting companies usually have access to relatively low cost international bank lines guaranteed by their export cash flow. With the exception of the export dummy, the other variables, by and large, behaved in accordance with our H5 hypothesis.

\section{Conclusions}

Contrary to the various positive views put forward regarding the recovery of the world economy, Roubini (2009) believed that the crisis was in its initial stages, that there are many bubbles that still have to be burst and that assets will probably continue to lose value. Shiller (2009) forecast that the world economy would not recover in the short term. The advent of discounts (haircuts) on securities that served as collateral in the repo market, highlighted by Gorton and Metrick (2012), were at the root of bank runs in this market and led to a credit crunch. We investigated if the intensity, composition and determinants of international financing of Brazilian non-financial companies changed from before to during the crisis.

The Eurobond issuance of Brazilian companies relative to its GDP is small compared to that of other emerging economies. There is more foreign debt financing when the Brazilian real is stronger.

We compared end-of-the-year capital structure indicators for a year that was clearly removed from the crisis period (2004) with the same kind of information for the crisis year of 2008. We did not look into more recent years, in which there was a partial recovery, at least in many emerging markets and some developed markets, because we wanted to examine the potential consequences of the 2008 financial crisis and ensuing credit crunch. We examined only non-financial Brazilian listed companies.

Short-term financing decreased substantially by the end of 2008 while long-term finance increased. The average share of bank loans, both domestic and foreign, decreased, while bond issuance, both domestic and foreign, increased in the same period. This suggests that bank loans were partially replaced by bond issuance. The percentage of companies using international bank loans decreased substantially, while there was no significant change in the percentage of companies using Eurobonds and a slight increase in the percentage of companies issuing ADRs. Previous works could lead us to believe that Brazilian companies, potentially more credit-constrained, would switch into more short-term domestic financing in periods of crisis; however, this did not happen. Maybe the nature of this crisis, a major bank credit crunch, led to a different behavior, with a significant reduction in the use of bank loans, both domestic and international. Financial expenditures increased, but not significantly, even in the event of the rise in country risk and credit crunch. Average profitability and relative market values were much less by the end of the crisis year than in 2004. These results suggest that short-term bank loans may have been partially replaced by long-term debt securities, and maybe equity in some cases, when we compare pre-crisis to year-end figures of the crisis year. However, we cannot attribute this trend to the crisis because other relevant events, such as the success of the premium listing segments of BM\&FBovespa, may have significantly contributed to it. 
Larger firms employ all foreign financing sources more often and much more intensively. When a firm uses international bank loans it also tends to use Eurobonds and ADRs more often. Firms examined that use all sources of international financing tend to score better in corporate governance practices, are export oriented, and include foreign shareholders. Firms that are certainly less financially constrained, such as those using all of the international financing sources, seem to have replaced international bank loans with bond issues, domestic and foreign. The use of the domestic bond market is not significantly different between firms with and without foreign financing. Firms that issue securities abroad achieve higher corporate governance scores and have foreign shareholders more frequently. We noticed no major change in the potential determinants of capital structure from the pre-crisis to the crisis year, which were consistent both before and during the crisis with previous Brazilian evidence.

Firms without international bank loans are probably among the most financially constrained among non-financial Brazilian firms because they also employed significantly fewer domestic bank loans and rarely rely on Eurobonds. On the other hand, companies that issued Eurobonds also exhibited significantly more international bank loans and significantly fewer domestic bank loans, suggesting that they have replaced higher cost domestic bank loans with international financing, possibly becoming less constrained. Our results suggest that international bank loans may be the first step towards a broader use of international financing sources and that their presence may indicate less financially constrained firms. The absence of international bank loans may be a stronger proxy for financial constraint than the absence of ADRs, for instance.

We did not measure credit-constraint directly, but simply assumed that larger firms that use fewer international bank loans are among the most credit-constrained non-financial listed firms in Brazil. We also did not employ a theoretical model that offers direct testable hypotheses of the effect of this specific financial crisis over firms in Brazil. We have simply compared two years and inferred credit-constraint from firm characteristics. These limitations render our results as preliminary and warrant avenues for future research. In particular, credit-constraint could be measured through more detailed firm information, as well as firm declarations, and the specific effects of the crisis could be gauged on firms classified as such, using a more complete panel of firm-years and more detailed firmlevel debt information. Finally, the impact of regulatory change after the crisis on the international financing of Brazilian companies is unknown and opens a new path for future research.

\section{References}

Acharya, V. V., \& Richardson, M. (Orgs.) (2009). Restoring financial stability: how to repair a failed system. New York, NY: Wiley.

Acharya, V. V., Gale, M., \& Yorulmazer, T. (2011). Rollover risk and market freezes. Journal of Finance, 66(4), 1177-1209. doi: 10.1111/j.1540-6261.2011.01669.x

Azevedo, A. F. Z. de, \& Terra, P. R. S. (2009). Building resilience to international financial crisis: lessons from Brazil. Critical Perspectives on International Business, 5(1/2), 141-156. doi: $10.1108 / 17422040910938758$

Bacha, E., \& Goldfajn, I. (Org.) (2009). Como reagir à crise? Políticas econômicas para o Brasil. Rio de Janeiro: Imago.

Barros, L. A. B. C. de, \& Silveira, A. M. da (2008). Excesso de confiança, otimismo gerencial e os determinantes da estrutura de capital. Revista Brasileira de Finanças, 6(3), 293-335.

Barros, O., \& Giambiagi, F. (Orgs.) (2009). Brasil pós-crise: agenda para a próxima década. Rio de Janeiro: Campus. 
Brunnermeier, M. K. (2009). Deciphering the liquidity and credit crunch 2007-2008. Journal of Economic Perspectives, 23(1), 77-100. doi: 10.1257/jep.23.1.77

Campello, M., Graham, J., \& Harvey, C. (2010). The real effects of financial constraints: evidence from a financial crisis. Journal of Financial Economics, 97(3), 470-487. doi: 10.1016/j.jfineco.2010.02.009

Comissão de Valores Mobiliários (n.d.). Informações sobre as Companhias Abertas. Retrieved October, 2009, from http://www.cvm.gov.br

Costa, C. M., Paz, L. S., \& Funchal, B. (2008). Fluxo de caixa, ADRs e restrições de crédito no Brasil. Brazilian Business Review, 5(2), 144-151.

Crisóstomo, V. L. (2009). Dificuldades das empresas brasileiras para financiar seus investimentos em capital físico e inovação. Revista de Economia Contemporânea, 13(2), 259-280. doi: 10.1590/S1415-98482009000200004

Dooley, M., \& Hutchison, M. (2009). Transmission of the U.S. subprime crisis to emerging markets: evidence on the decoupling-recoupling hypothesis. Journal of International Money and Finance, 28(8), 1331-1349. doi: 10.1016/j.jimonfin.2009.08.004

Economatica - Tools for Investment Analysis (n.d.). Base de dados. São Paulo: Author.

Eichengreen, B., \& Baldwin, R. (Orgs.) (2008). Rescuing our jobs and savings: what G7/8 leaders can do to solve the global credit crisis. London: Center for Economic and Policy Research. Retrieved from http://www.voxeu.org/index.php?q=node/2327

Frank, M. Z., \& Goyal, V. K. (2008). Trade-off and pecking order theories of debt. In B. E. Eckbo (Ed.), Handbook of empirical corporate finance (Vol. 2, pp. 135-202). Amsterdam, Netherlands: North-Holland.

Gorton, G. B. (2009). Slapped in the face by the invisible hand: banking and the panic of 2007 [Working Paper]. Social Science Research Network. Retrieved from http://ssrn.com/abstract=1401882

Gorton, G. B., \& Metrick, A. (2009). Haircuts [Working Paper n. 9-15]. Yale School of Management, International Center for Finance, New Haven, USA. Retrieved from http://ssrn.com/abstract $=1447438$

Gorton, G. B., \& Metrick, A. (2012). Securitized banking and the run on repo. Journal of Financial Economics, 104(3), 425-451. doi: 10.1016/j.jfineco.2011.03.016

Helleiner, E., \& Pagliari, S. (2010). Crisis and the reform of international financial regulation. In E. Helleiner, S. Pagliari, \& H. Zimmermann (Eds.), Global finance in crisis: the politics of international regulatory change (pp. 1-18). Abingdon, UK: Routledge.

Ivashina, V., \& Scharfstein, D. S. (2010). Bank lending during the financial crisis of 2008. Journal of Financial Economics, 97(3), 319-338. doi: 10.1016/j.jfineco.2009.12.001

Kalatzis, A. E. G., \& Azzoni, C. R. (2009). Investment decisions in troubled times: a Bayesian approach applied to Brazilian firms. International Journal of Production Economics, 120(2), 595-606. doi: 10.1016/j.ijpe.2009.04.009

Kirch, G., Terra, P. R. S., \& Procianoy, J. L. (2010, July). Restrições ao crédito, tangibilidade e decisões de investimento. Anais do Encontro Brasileiro de Finanças, São Paulo, SP, Brazil, 10.

Leal, R. P. C. (2008). Estrutura de capitais comparada: Brasil e mercados emergentes. Revista de Administração de Empresas, 48(4), 67-78. doi: 10.1590/S0034-75902008000400007 
Leal, R. P. C. (2010). The emergence of a serious contender - corporate governance in Brazil. In C. Mallin (Ed.), Handbook on international corporate governance - Country analyses (2nd ed., pp. 317-329). Cheltenham, UK: Edward Elgar Publishing.

Leal, R. P. C., \& Carvalhal-da-Silva, A. L. (2007a). Corporate governance and value in Brazil (and in Chile). In A. Chong \& F. Lopez-de-Silanes (Eds.), Investor protection and corporate governance: firm level evidence across Latin America (pp. 213-288). Palo Alto, CA: Stanford University Press.

Leal, R. P. C., \& Carvalhal-da-Silva, A. L. (2007b). O financiamento externo no ciclo recente da economia brasileira [Working Paper LC/BRS/R. 183]. Economic Commission for Latin America and the Caribbean, United Nations, Santiago, Chile. Retrieved from http://www.eclac.cl/brasil/publicaciones/xml/3/29373/LCBRSR183LeaLCarvalhal.pdf.

Levine, R. (2012). The governance of financial regulation: reform lessons from the recent crisis. International Review of Finance, 12(1), 39-56. doi: 10.1111/j.1468-2443.2011.01133.x

Lima, F. G., Assaf, A., Neto, Perera, L. C. J., \& Silva, A. C., Filho (2011). The impacts in the capital structure of Brazilian companies during periods of crises. Journal of International Finance and Economics, 11(2), 154-160.

Organization for Economic Cooperation and Development. (2009). The financial crisis: reform and exit strategies. Paris, France: Authors.

Portal, M. T., Zani, J., \& Silva, C. E. S. (2012). Fricções financeiras e a substituição entre fundos internos e externos em companhias brasileiras de capital aberto. Revista Contabilidade \& Finanças, 23(58), 19-32. doi: 10.1590/S1519-70772012000100002

Roubini, N. (2009). Warning: more doom ahead. Foreign Policy, 170, 63-64.

Shiller, R. J. (2009). Are we there yet? Foreign Policy, 170, 67.

Silveira, A. M. da, Leal, R. P. C., Barros, L. A. B. C. de, \& Carvalhal-da-Silva, A. L. (2009). Evolution and determinants of firm-level corporate governance quality in Brazil. Revista de Administração, 44(3), 173-189.

Sternberg, L., Leal, R. P. C., \& Bortolon, P. M. (2011). Affinities and agreements among major Brazilian shareholders. International Journal of Disclosure and Governance, 8(3), 213-228. doi: $10.1057 / j d g .2011 .6$

Tanoue, L. (2010). Cuidado com a Dodd-Frank. Capital Aberto, 8(85), 17-19.

Terra, M. C. T. (2003). Credit constraints in Brazilian firms: evidence from panel data. Revista Brasileira de Economia, 57(2), 443-464. doi: 10.1590/S0034-71402003000200006

Zimmermann, H. (2010). Conclusion - Whither global financial regulation? In E. Helleiner, S. Pagliari, \& H. Zimmermann (Eds.), Global finance in crisis: the politics of international regulatory change (pp. 170-175). Abingdon, UK: Routledge. 


\section{APPENDIX}

\section{Probit Model Variable Definition}

\begin{tabular}{|c|c|}
\hline Variable & Definition \\
\hline \multicolumn{2}{|c|}{ Dependent variables: } \\
\hline ADRs & Dummy variable that takes the value 1 if the firm issued ADRs \\
\hline Eurobonds & Dummy variable that takes the value 1 if the firm issued Eurobonds \\
\hline IntBanks & Dummy variable that takes the value 1 if the firm had international bank loans \\
\hline \multicolumn{2}{|c|}{ Explanatory variables: } \\
\hline CGI & $\begin{array}{l}\text { Score of a corporate governance index created and described in Leal and Carvalhal-da- } \\
\text { Silva ( } 2007 \text { a). The index consists of } 20 \text { questions. Each question represents a good } \\
\text { corporate governance practice that can be verified from public filings with the Brazilian } \\
\text { Securities Commission. A positive answer to a question represents the existence of a } \\
\text { good corporate governance practice and adds } 1 \text { to the index. }\end{array}$ \\
\hline $\mathrm{E}$ & $\begin{array}{l}\text { Company exports is a dummy variable that assumes the value } 1 \text { if a company is an } \\
\text { exporter }\end{array}$ \\
\hline $\mathrm{F}$ & $\begin{array}{l}\text { Company foreign shareholder is a dummy variable that assumes the value of } 1 \text { if there } \\
\text { is a relevant foreign shareholder, one with more than } 5 \% \text { of the equity capital }\end{array}$ \\
\hline Q & $\begin{array}{l}\text { Tobin's Q represents growth potential because it is a quotient of the market value of a } \\
\text { company relative to assets in place, with the excess of market over book value } \\
\text { representing growth potential. It was computed as the ratio between the market to book } \\
\text { value of assets; the market value of assets was computed as the market value of equity } \\
\text { plus the book value of assets minus the book value of equity at year end }\end{array}$ \\
\hline ROA & $\begin{array}{l}\text { Return on assets represents asset profitability, disregarding the impact of leverage, } \\
\text { computed as the ratio of earnings before interest and taxes to total assets }\end{array}$ \\
\hline $\mathrm{S}$ & Company size represented by the natural logarithm of total assets \\
\hline $\mathrm{T}$ & $\begin{array}{l}\text { Company asset tangibility denoting the proportion of a company's fixed assets and } \\
\text { computed as fixed assets over total assets }\end{array}$ \\
\hline $\mathrm{V}$ & $\begin{array}{l}\text { Company stock volatility is the annualized standard deviation of daily local currency } \\
\text { stock returns during the year }\end{array}$ \\
\hline
\end{tabular}

